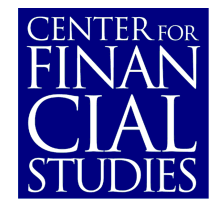

No. $2003 / 34$

\title{
Courts and Sovereign Eurobonds: Credibility of the Judicial Enforcement of Repayment
}

Issam Hallak

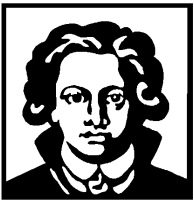

Center for Finandia Studies 


\title{
Courts and Sovereign Eurobonds: Credibility of the Judicial Enforcement of Repayment
}

\author{
Issam Hallak*
}

October 2003

\begin{abstract}
:
While focusing on the protection of distressed sovereigns, the current debate intended to reform the International Financial Architecture has hardly addressed the protection of creditors rights that varies among laws. I suspect however that this constitutes an essential determinant of the success of suggested solutions, especially under the contractual approach. Based on a sample of bonds issued by developing countries states in the period, January 1987 to December 1997, I find that, for given contract characteristics (e.g. listing markets and currency), the governing law is selected according to its ability to enforce repayment. However, although the New York law seems looser and incur larger enforcement costs than the England\&Wales law, the former permits equivalent yearly credit amounts. I interpret this as a consequence of the existence of a larger set of valuable assets (e.g. trade) in the US that constitute implicit securities. My findings yield important implications for the reforms. In particular, provided that there exists a seemingly equivalent enforcement credibility between England and New York laws, the prompt implementation of the contractual approach solution should constitute a valuable first step toward efficient sovereign debt markets.
\end{abstract}

JEL Classification: F34; G33; K33

Keywords: Law and Finance; Sovereign Debt Restructuring Mechanism; Collective Action Clause; Bankruptcy; Creditor Rights Protection

\footnotetext{
* Corresponding author: Center for Financial Studies at Goethe-University Frankfurt, Taunusanlage 6, 60329Frankfurt am Main, Germany, Email: hallak@ifk-cfs.de.

For valuable discussions and/or comments, I am especially indebted to Nadja Calabrò, James Dow, Jan Pieter Krahnen, and Andrew Yianni. For assistance with the data, I am very thankful to Soheil Safadeh. This research received the support from grants awarded by the European Commission Research and Training Network Understanding Financial Architecture: Legal and Political Frameworks and Economic Efficiency.
} 
"Exploring ways to improve the sovereign debt restructuring process is a key part of the international community's efforts to strengthen the architecture of the global financial system."

Anne O. Krueger, First Deputy Managing Director of the International Monetary Fund.

\section{Introduction}

The recent and spectacular financial distresses of sovereign states of large emerging economies, e.g. Mexico (1995), East Asia (1997), Russia (1998) and Argentina (2002) have raised growing concerns regarding the economic inefficiency of the current international legal frames of sovereign debts. The debate that emerged, have been reconsidering the international financial architecture and the implementation of reforms that would help improve financial distress workouts of sovereign debtors. If there is a general agreement on supporting collective action among lenders similarly to English \& Welsh law that requires a majority of debt holders (usually $75 \%$ ) to modify repayment terms, opinions still diverge regarding its implementation.

The contractual approach suggests that the so-called collective action clause (CAC) would either become a standard covenant included in bond contracts (e.g. Yianni (1999), Eichengreen and Mody (2000b), Buchheit and Gulati (2002), Kletzer (2002)) or be introduced through amendments in major governing laws. In either of the two forms, the financial community supports this solution. ${ }^{1}$ The statutory approach suggests instead the creation of an official Sovereign Debt Restructuring Mechanism (SDRM). An independent supervisory agency would be established, the International Monetary Fund (IMF) being a suitable candidate through the modification of its statutes. This solution is strongly supported by Anne O. Kruger, IMF first deputy managing director (Krueger (2002); see also Bolton and Jeanne (2002)). A key difference between these approaches resides in the way decisions will be taken. While clauses bind holders only within the same bond issue, the SDRM would allow 
for different bond instruments to be aggregated into one single vote on the proposed restructuring, as in commercial debt restructuring (see e.g. White (2002) for a valuable discussion of the two approaches).

I believe that the outcome of each of these propositions depends to a large extent on the variation in the protection of the rights of creditors among the various laws. Indeed, maintaining unbalanced creditor rights protection is likely to result in hazardous restructurings. For instance, holders of debts governed by strong creditors rights protection may block any restructuring because the value of their collateral is implicitly larger. As a consequence, the distressed sovereign will offer larger compensations than it would necessary be otherwise in order to prevent an official default due to a minority of creditors. In this case, the contractual collective-action clause (so-called, CAC) would be insufficient and might become in some cases counter-productive. Hence, I believe the thorough understanding of creditor rights under each law is essential. Nevertheless, in its attempt to provide enhanced protections to sovereign debtors, the current debate has dismissed this point. This paper suggests bridging the gap.

What actually happens today is that ad-hoc national laws govern sovereign debt contracts. The so-called governing law constitutes the only legal frame for every individual debt contract. Although the immunity of foreign states remains the general rule, major governing laws are inclined to breach the doctrine of sovereignty and adopt the restrictive doctrine of foreign state immunity. Provisions mainly apply to commercial activities which states carry out abroad. Unlike corporate debts, the governing laws of sovereign debts have strong implications on the restructuring and the enforcement of the terms of the contract (Wood (1995)). Beyond that, the governing laws are conflicting if not competing, which is

\footnotetext{
${ }^{1}$ See for instance the intervention of Joseph Ackerman, Spokesman and Chairman of the Group Executive Committee, Deutsche Bank, in Financial Times, September 26, 2002
} 
not the case for firms, which may opt to submit to the jurisdiction they like (Ayotte and Skeele (2002)).

I find evidence that the governing law is indeed selected in order to favour the lenders' ability to take legal action against the sovereign defaulter. Hence, the relevance of the governing law seems to be a prerequisite to gain access to international capital markets. The second result is that the credibility and the enforcement costs associated with each law will have an impact on the size of the debts (yearly and relative to GNP). The two major governing laws, namely England and New York do not present substantial differences though. Therefore, I believe the contractual approach should not suffer from unbalanced bargaining power among lenders. It would indeed constitute a first major step in the sense of the improvement of the economic efficiency of international financial architecture.

The results are consistent with previous evidence suggesting that the asset value and contracted amounts are larger under laws that provide stronger creditors rights and enforcement (e.g. La Porta et al. (1999), Fabbri and Padula (2001)). ${ }^{2}$ The results are also consistent with the hypothesis that the presence of threats of commercial penalty motivates the presence of sovereign debts (Bulow and Rogof (1989), Rose (2002)).

The rest of the paper is organised as follows. Section 2 makes a comparative analysis of national laws and jurisprudence, with a comprehensive survey of the US and English\&Welsh codes. Section 3 draws the consequences for the choice of the governing law and its determinants. Section 4 then presents the sample of sovereign public issues and descriptive elements of the governing laws. Section 5 presents the results and the robustness tests. In the last section I summarise the results and provide concluding remarks.

\footnotetext{
${ }^{2}$ See Euromoney October 2002 Vol. 33, no. 402, p.66-69, "Nigeria rewrites the rule book" by Felix Salmon.
} 


\section{National laws: ad-hoc international legal frames for sovereign debts}

First and foremost, I shall specify that the following analysis applies to foreign states. National states should be viewed most often as immune agents in their own jurisdictions. This said, it is the general rule that states benefit of legal immunity in foreign countries. Among the commonly adopted governing laws, I know none of them that has not adopted the doctrine of foreign state immunity. Nevertheless, jurisprudence and, more recently, codes have implemented exceptions for which the sovereign immunity should not apply. This is known as the restrictive view of sovereign immunity. There are three major issues associated with the determination of the deimmunisation of foreign states entering into commercial activities, and more specifically loan transactions. First, the definition of foreign states varies. Second, the judicial court must determine the "commercial activity" feature of the transaction. Third, the jurisdiction should be relevant (forum conveniens). These three elements constitute the guidelines to the following comparative analysis.

2.a. The adoption of the restrictive doctrine of sovereign immunity in national jurisdictions.

Table 1 presents a non-exhaustive list of countries that adopted the restrictive doctrine of foreign states immunity. The judicial decisions apply to commercial activities which are not necessarily credit facilities. Interestingly, English origin laws only (origin law classification follows La Porta et al. (1997)) have codified the restrictions on sovereign immunities. The new acts were adopted in the United States (1976), United Kingdom (1978), Singapore (1979), South Africa (1981), Pakistan (1981), Canada (1982), and Australia (1985). The codification contrasts with the jurisprudence exercised in other countries, in particular Continental Europe.

The family of French origin laws have mixed implementation of foreign states immunity. If Belgium and Italy are considered as the forerunners in the adoption of the restrictive doctrine of sovereign immunity, France is actually lagging. In Belgium and Italy, judicial 
decisions of deimmunisation are essentially related to building contracts and farming loans. Instead, France has historically adopted a narrow version of the restrictive doctrine despite recent changes. Generally speaking, the situation in France remains broadly unclear unlike in Belgium and Italy, although it seems that the commercial approach would prevail. The jurisprudence therefore tends to deimmunise foreign states which enter into commercial transactions.

Among German origin laws, Switzerland has had a long tradition of the narrowest view of the doctrine of foreign state immunity. The Swiss court takes however action only if there is a substantial connection (Binnenbeziehung) between the activity and the Swiss jurisdiction. For example, jurisprudence predicts that a connection is acknowledged where payment of the bonds is required by the contract to be made in Switzerland (Dreyfus case, 1918). The restrictive view of the forum conveniens will prevent the Swiss law from being a major governing law of sovereign debts. Still, provided the strong and traditional commitment of Swiss courts in the waiving of foreign state immunities, Helvetian law constitutes a precious means of enforcement available to the creditor. Germany is also little specific despite the precedence of international over national laws. Conversely, Japan has adopted the absolute immunity rule. However jurisprudence is scarce and includes only one case. ${ }^{3}$

Of English origin laws, UK and US legislations deserve most attention. The motivation is twofold. On the one hand, the codification allows a clearer reading of the exceptions on sovereign immunity. Second, both England and New York laws are well known for being the major governing laws of sovereign debt contracts. Nevertheless, despite their similar view of the restrictive doctrine, the two acts diverge on essential definitions. They also diverge in their specificity. The next section is intended to highlight these differences through a comparative analysis.

\footnotetext{
${ }^{3}$ Matsuyama \& Sano v. Republic of China (1928), 7 Dai-han Minroku 1128.
} 


\section{2.b. The US Foreign Sovereign Immunities Act 1976 (FSIA)}

The US Foreign Sovereign Immunities Act (FSIA, thereafter) of 1976 came into force in January 1977 and is retroactive to outstanding contracts signed earlier. The act on sovereign states immunity is first aimed to adopt the restrictive doctrine of sovereign immunity. Although foreign states immunity is codified, exceptions are set down.

Foreign State. The act defines foreign state in the following manner:

$\S$ 1603. Definitions $[\ldots]$

(a) A "foreign state" [...] includes a political subdivision of a foreign state or an agency or instrumentality of a foreign state as defined in subsection (b).

(b) An "agency or instrumentality of a foreign state" means any entity -

(1) which is a separate legal person, corporate or otherwise, and

(2) which is an organ of a foreign state or political subdivision thereof, or a majority of whose shares or other ownership interest is owned by a foreign state or political subdivision thereof, [...]

Any entity involved by this definition of foreign state thus benefits of sovereign immunity unless restrictions apply. This is actually a rather broad definition of a foreign state that covers most of public firms.

Commercial activity. In the FSIA, there is ambiguity in the definition of the commercial activity itself which constitutes the core paragraph of the act since it determines the exception for which the state is not immune. A commercial activity must be carried on in the US by a foreign state. This is defined as follows:

(d) A "commercial activity" means either a regular course or commercial conduct or a particular commercial transaction or act. The commercial character of an activity shall be determined by reference to the nature of the course of conduct or particular transaction or act, rather than by reference to its purpose. (e) A "commercial activity carried on in the United States by a foreign state" means commercial activity carried on by such state and having substantial contact with the United States.

Hence commercial activity means either a regular course of commercial conduct or a particular commercial transaction or act. The commercial character is determined by the nature of the conduct or act, and not its purpose. It is however unclear whether a loan contracted by a state should be deemed as a commercial transaction. 
A contact presumably includes negotiation and signature of financial contracts involving US creditors or merely repayable in the US. It is questionable whether the term contact also involves any dollar denominated lending. Interestingly, although interpretations generally involve financial contracts that enter the exception clauses, attempts to amend the code in a specification purpose, especially the amendment proposed by Senator Mathias in 1984 (which followed the UK Sovereign Immunity Act 1978, more specific on this matter) was rejected. The statement was the following:

any promise to pay made by a foreign state, any debt security issued by a foreign state, and any guarantee by a foreign state of a promise to pay made by another party ${ }^{4}$

The act has been amended in 1988 though, introducing the following statement: ${ }^{5}$

28 U.S.C. $\S 1605(\mathrm{~A})$

(6)in which the action is brought, either to enforce an agreement made by the foreign state with or for the benefit of a private party to submit to arbitration all or any differences which have arisen or which may arise between the parties with respect to a defined legal relationship, whether contractual or not, concerning a subject matter capable of settlement by arbitration under the laws of the United States, or to confirm an award made pursuant to such an agreement to arbitrate, if (A) the arbitration takes place or is intended to take place in the United States, (B) the agreement or award is or may be governed by a treaty or other international agreement in force for the United States calling for the recognition and enforcement of arbitral awards, (C) the underlying claim, save for the agreement to arbitrate, could have been brought in a United States court under this section or section 1607, or (D) paragraph (1) of this subsection is otherwise applicable.

Therefore, ambiguities regarding the financial contracts have been left out by the legislator. The Allied case jurisprudence actually predicts that the loss of time consecutive to the ambiguity of the FSIA give time for politics to reflect on the case. Indeed, the argument for dismissal of the Act of State doctrine was denied by the government only several years later and concluded the debate (Leigh (1984) and Greenwood and Mercer (1995)).In 1992, the decision of the United States Supreme Court regarding the case Republic of Argentina $v$. Weltover, Inc $^{6}$ has removed the ambiguity as to the commercial nature of the public debt of foreign states.

\footnotetext{
${ }^{4}$ in Atkeson and Ramsey (1985) cited by Delaume (1994).

${ }^{5}$ An additional amendment was enacted in 1996 against terrorism. Despite its political importance, it is of little relevance in this study.

${ }^{6} 112$ S.Ct. 2160. US Supreme Court, June 12, 1992; 31 ILM 1220 (1992). Summarised in Pizzurro (1992)
} 
In approaching the issue of whether the defendants' acts were sovereign of commercial, the Court noted that, while the FSIA contained a definition of "commercial activity", it left the critical term "commercial" largely undefined. [...] The Court held "that when a foreign government acts [...] in the manner of a private player within [the market], the foreign sovereign's actions are 'commercial' within the meaning of the FSIA. ${ }^{7}$

\section{2.c. The UK State Immunity Act 1978 (SIA)}

English \& Welsh law introduced the State Immunity Act (SIA, thereafter) in 1978 taking effect the same year with no retroactive effect on contracts signed by the date of enactment. Similar to the US FSIA 76, the UK SIA 78 adopted the restrictive doctrine of the sovereign immunity and was aimed at giving guidelines in international commercial disputes. The Act also enabled the United Kingdom to ratify the European Convention on the State Immunity of 1972.

Foreign State. The act states the sovereign immunity of the state unless a few exceptions apply. A state is defined as any foreign or commonwealth state. Under the English Act the political subdivisions that benefit of the sovereign immunity is limited to the state, the government of this state, and any department of this government. Separate entities benefit of immunity to a lesser degree which should be compared to "any agency or instrumentality of a foreign state."

Commercial activity. The UK act removes all doubts regarding the commercial feature of the borrowing activity:

Section 3(1) A State is not immune as respects proceedings relating to--

(a) a commercial transaction entered into by the State $[\ldots]$

Section 3(3) In this section "commercial transaction" means--

(b) any loan or other transaction for the provision of finance and any guarantee or indemnity in respect of any such transaction or of any other financial obligation

Loan transactions are explicitly included in the definition of the "commercial activity" for which foreign states benefit from no immunity.

\footnotetext{
${ }^{7}$ Pizzuro (1992)
} 
Jurisdiction. Unlike the United States courts, the mention of the English law as the governing law in the commercial transaction is sufficient for the English courts to create jurisdiction:

Exceptions from [jurisdiction] immunity

Section 2(1) A State is not immune as respects proceedings in respect of which it has submitted to the jurisdiction of the courts of the United Kingdom.

The English courts "could nevertheless claim jurisdiction if, inter alia, the loan agreement is expressly or impliedly governed by the English Law: they could then apply the UK Act." (Wood (1995) p. 142, section 14-47, Jurisdiction). Hence, the inclusion of the English law as the contract's governing law is a sufficient condition for the UK Act to become applicable and creating jurisdiction in England.

\section{Comparative summary}

Foreign state. The definition in the UK act is narrower and is set to include only state and government entities. The US act instead covers firms in which the foreign state holds a majority of shares or of votes.

Commercial activity. Both acts constrain sovereign immunities and deny the latter in commercial transactions entered into by the foreign state. However, if the UK code explicitly states loans as being a commercial activity, the US act remains ambiguous. The latter also specify that the commercial transaction should have direct impact on the USA. Although the New York jurisprudence have assimilated some loans as being a commercial activity having an impact on the USA, the interpretation of the impact varies from the currency determination (US Dollars) to the country where arbitrage takes place.

Jurisdiction. The US act provides clearer insights on these regards since the statement that a federal law governs the transaction is sufficient to create jurisdiction in the respective federal state. Although the UK act is less specific, there are good reasons to believe that the Act applies after the courts create jurisdiction. 
The UK act is therefore more specific and gives rise to almost no ambiguities: if a state enters into a loan transaction governed by England law, it automatically submits to English courts which according to the State Immunity Act 1978 will remove its immunity. On the other hand, the inaccurate US FSIA 1976 exposes the creditor who attempts to sue the sovereign defaulter to higher risks of failure. Delaume (1994) also showed the judicial cases were time-consuming in the USA. As a consequence, the England law should be regarded as a governing law that incurs substantially lower enforcement costs and less uncertain judicial decisions.

\section{The selection of the governing law of sovereign debts}

The comparative law analysis presented in the previous section yields several implications. First, the enforcement of the terms of a sovereign loan contract is apparently contingent on various features of the contract itself with respect to the governing law, e.g. "direct impact", "substantial connection". On top of that, the specificity of the act is likely to affect the decision to make a repayment claim in courts. I remind that the US FSIA 1976 is little precise relatively to the UK SIA 1978 making judicial decisions relatively uncertain and suing costly. Conversely, the England \& Wales code precisely regards all loans entered into by a foreign state as a commercial transaction and raises no ambiguities regarding the immunity waiving. Judicial inefficiency has been acknowledged to having high economic costs in credit markets, especially on the availability of credits (Jappelli et al. (2002)). The UK act or any law put in the efficient context is therefore likely to increase the availability of funds. However, the US FSIA 1976 is likely to decrease the common pool problem if compared with the UK act. Part of the answer to the question whether the governing law matters or not is related to the following two questions. First, is the design of the governing law determined by its probability of enforcing repayment? Second, does the enforcement credibility have a positive impact on foreign credits availability? 
3.a. Is the governing law designed according to its enforcement power?

The analysis of the design of the governing law of sovereign international bonds will provide first evidence of whether the governing law functions as an enforcement device in sovereign debt markets. Following the survey provided here above, I suggest a combined survey of the governing law, the currency of denomination, and the countries where the liability is traded. Indeed, on the one hand, the law of the country where it is traded does not necessarily govern the bond. On the other hand, it may actually be traded in more than one market. As I showed in section 2, currency denomination and listing are the main factors of the probability of the law enforcement effectiveness.

The results should be interpreted in the following manner. The application of England law is not contingent on neither the place of listing nor the currency of denomination. Instead, New York law needs a direct impact on the US. Therefore most of debts that are governed by US law are either in US dollars or traded in the US. The same result applies to Swiss law, which requires substantial linkage with Switzerland. On the other hand, Japan law has no restrictive elements of foreign states immunity and therefore it will not be designed, should the governing law matter.

Broadly speaking, the context in which governing laws are selected predicts their importance in international as well as in domestic markets. The analysis is however insufficient. I will complete the analysis by exploring whether the amounts raised under different governing laws are significantly different.

\section{3.b. Does jurisdiction shopping ${ }^{8}$ allow for larger foreign credits availability?}

Assuming that the enforcement credibility of the governing law is real, the sovereign agent will raise more or less under the diverse governing laws. Indeed, following the

\footnotetext{
${ }^{8}$ The expression "Venue Shopping” stems from Ayotte and Skeel (2002).
} 
hypothesis that the low enforcement power of the contract terms has a credit rationing effect, I expect the weak laws to allow for lower amounts. To investigate this hypothesis, I suggest the following statistical model:

$$
\begin{aligned}
\text { Yearly amounts to } \text { GNP }_{i, j, k} & =\text { constant }_{i, j, k} \\
& +\alpha_{1} . \text { Germany }_{i, j, k}+\alpha_{2} . \text { Japan }_{i, j, k}+\alpha_{3} .{\text { New } \text { York }_{i, j, k}} \\
& +\alpha_{4} . \text { Debt to } \text { GNP }_{i, j, k}+\text { Errors }_{i, j, k}
\end{aligned}
$$

where subscripts $i, j, k$, respectively indicate $i$ th country, $j$ th year, and $k$ th governing law. Yearly amounts to GNP are yearly amounts of bond debts issued by a given country and governed by a given law relative to the given country's GNP. The ratio provides relative amounts of debts in a given governing law. Germany, Japan, and New York are dummy variables that indicate whether the group of bonds is issued respectively under German, Japanese and New York laws. Note that, provided that all other laws govern a marginal amount of Euro-bonds, the analysis applies only to bonds that are issued under England, Germany, Japan and New York laws. Moreover, the benchmark law is England and is not included in the equation. Because of enforcement constraints, I expect Germany and Japan to allow for lower amounts and therefore $\alpha_{1}$ and $\alpha_{2}$ to be negative. On the other hand, New York is supposedly more costly, although recent jurisprudence has shown that for a well-designed debt (having a "direct impact" on the United States), enforcement power is likely to be alike. On the other hand, submitting to New York courts will allow the attachment ${ }^{9}$ of a larger set of assets since the United States attract a large share of the world economic activity. The prediction of results is therefore uncertain.

The Debt to GNP variable is calculated as the total outstanding debts of public entities in the issuing country relative to the country GNP. All macroeconomic variables are obtained from the World Bank databank Global Development Finance. The ratio is aimed to include a

\footnotetext{
${ }^{9}$ Attachment of assets is the lawful seizure of property and placing it under the control of the court.
} 
debt indicator in the model. I expect that the debt to GNP ratio has a positive impact on the amounts issued under each governing laws.

\section{Data sampling and description}

The data is collected from various issues of the International Financing Review. I selected all bonds issued or guaranteed by sovereign states (pure sovereign) in the period January 1987 - December 1997. For specific reasons, public administrations and entities (quasi sovereign) and public firms were dismissed. January 1987 is the starting date from which the governing law is reported. The set of countries is constituted of all countries defined as Less Developed Countries by the World Bank in 1998, where more severe threats of default exist. The definition is based on per-capita income. The upper bound was then set to 9,655 thousands US dollars.

Tables II and III present the summary statistics of the sample. It is constituted of 329 bonds issued by pure sovereign agents in the period between January 1987 and December 1997. Of the 329 observations, 327 report the governing law making a loss of 0.6 percent only. ${ }^{10}$ Altogether, the 327 bonds are issued by 32 different sovereign states. Of the 327 observations reporting the governing law, 322 report the listing market and all report the currency of denomination.

Only eight national laws govern the 327 public debt contracts. England law governs the largest number of them (117), while New York comes second (85). Altogether, New York and England govern $62 \%$ of the loans in the sample. Germany (66) and Japan (49) are also highly represented with $35.2 \%$ of the sample. There are four additional governing laws, namely Austria (two observations), Luxembourg (one observations), Spain (two observations), and

\footnotetext{
${ }^{10}$ Two observations do not report the governing law. One of them was a bond issued by the Republic of Turkey (04 October 1991, presumably a private placement), the other one by the Republic of Latvia (private placement, 03 August 1995).
} 
Switzerland (five observations). However these governing can be viewed as marginal laws with a trivial $3.1 \%$ share. These results are identical to Eichengreen and Mody (2000b).

Surprisingly, in constant dollars volumes, New York law governs the largest share of public debts. ${ }^{11}$ The next section reports the results regarding the analysis of the credit availability by governing law.

\section{Results}

5.a. Is the governing law designed so to enhance the enforcement power?

Table IV presents a group analysis of the governing laws and the related listing markets and currencies of denomination. In particular, I look at the number of sovereign bonds denominated in the currency of the governing law and/or listed in the jurisdiction of the governing law. As detailed in section 2, it matters for the forum conveniens and the eligibility of bond for sovereignty restrictions. I also look at the Rule of Law rating provided by la Porta et al. (1997) for national law enforcement (see Table 1).

Interestingly, all selected laws have a very high rating of the Rule of Law. England is the lowest with 8.57. Most of other laws display a 10.0 rating. However, the main result of the combined analysis of governing laws, currencies, and listing markets is that issuers set governing laws of their tradable liabilities in accordance to their enforcement power given the listing markets and the currency. Among non-private placement bonds, New York law govern 67 non-private placement international bonds of which 59 are either denominated in US dollars or listed in New York. Only 8 are neither of them.

Besides, all bonds governed by Japanese law are listed in Tokyo, and vice-versa. All loans are denominated in Japanese Yen. The same applies to the German law: all 65 German

\footnotetext{
${ }^{11}$ Amounts are calculated in constant 1995 US dollars by using the Consumer Price Index - All urban consumers provided online by the US Bureau of Labor Statistics.
} 
law governed bonds are denominated in Deutsch Mark and traded in Germany. Last, England law governs all types of bonds whether they are listed in England or not (87 observations of 98 are not listed in England), and whether disbursements are made in UK Pounds or not (92 observations are not denominated in English pounds). A vast majority of the England law bonds are listed abroad and denominated in a foreign currency ( 84 out of 98 , that is $86 \%$ ).

Note that marginal governing laws (namely Austria, Luxembourg, Spain and Switzerland) are associated either with the currency or the country of the listing market. Interestingly, Luxembourg is the place of listing of a majority of tradable debts but the Luxembourg law governs seven contracts only. This is consistent with practitioners' analysis (e.g. Yianni (1999) and Rhodes (2001)).

Therefore, I find evidence that the governing law is not randomly designed. Instead, all bond loans governed by a given law are either denominated in the currency of the jurisdiction of the governing law or listed in this country. This provides evidence that the legal framework to some extent helps enforce contract terms of repayment.

\section{5.b. Jurisdiction shopping and foreign credits availability}

The second part of the investigation concerns the amounts raised by the countries under the different governing laws. Independently of the size of the country, the amounts raised under different laws should matter if the credit-rationing hypothesis holds. The sample includes 322 bonds issued between January 1987 and December 1997. Descriptive results are presented in Table VII.

I find average individual amounts relative to GNP are lower in German and Japan laws ( $0.24 \%$ of GNP), while New York law allows raising larger amounts on average at every issue $(0.85 \%)$. England is in between at $0.57 \%$. The debt creditworthiness indicator hardly is a factor of choice of governing law. Namely, more indebted countries would not issue under 
any specific law. For any governing law, the average ratio of outstanding debts to GNP of issuing countries is close to $40 \%$. Therefore, laws do not catch specific types of debtors according to creditworthiness.

I estimate Equation (1) using the ordinary-least squares method. results are reported in Table VIII. I find evidence that German and Japan laws allow for lower amounts relatively to England law at the level $0.01 \%$ and $0.03 \%$. The New York law provides mixed results. There seems to be no differences between England and New York laws. This contrasts with the survey of laws presented in Section 2. This could be interpreted in different manners. On the one hand, the two laws provide the same enforcement power under certain conditions despite probable longer periods of court procedures. On the other hand, involving New York courts gives the creditors higher chance of success of the seizure of the defaulter's assets.

Therefore, I find evidence that the governing law matters. The investigation however bears its limitation. I suspect it should be extended to take account for other factors such as asset seizure. For instance, the right-hand side of equation (1) may include other variables such as the sum of exports and imports vis-à-vis each of the governing law country. Moreover, the renegotiation process of bonds is essential as well, and therefore it should be taken into account in a subsequent study.

\section{Concluding remarks}

The paper explored whether the enforcement of governing laws of sovereign bonds are credible threats and whether they vary among major laws. Indeed, an essential difference among governing laws is their respective repayment enforcement power and costs. If policy makers decide to standardize collective actions in contracts or laws, the former will nevertheless subsist with hazardous consequences on the new frameworks. To the extent of my knowledge, this paper is the first one that addresses the heterogeneity of creditors rights 
protections in sovereign bonds. My findings yield important implications for the future reforms.

I find that the governing law is a credible enforcement device. The analysis is based on the selection process of the governing law. I find the jurisdiction is determined by a set of factors that will imply effectiveness of the enforcement of the sovereign defaulter. The second result is that sovereign liabilities are larger when governed by the UK and US law. The main implication of these findings is that there actually exists a legal threat that looks credible. In line with Rose (2002), this provides additional evidence to Bulow and Rogoff (1989) that predicts the existence of a "stick" to explain the presence of sovereign debts contracted from private creditors.

Therefore, if collective action clauses were widely implemented, I suspect no unbalanced bargaining powers among creditors due to varying governing laws enforcement powers. I therefore believe that the CAC should be promptly implemented as a major step toward the fully efficient international sovereign capital markets.

The study should be regarded as the first analysis of the governing laws of sovereign tradable borrowings that draws new avenues of research. One valuable extension is the analysis of the determinants of the portfolio of governing laws the sovereign debtor holds at every year's end. The jurisdiction shopping is likely to respond to macroeconomic indicators of creditworthiness, which should be interesting to investigate further. I believe having only one governing law versus diversifying the portfolio of governing laws is also a strategic choice of the sovereign debtors. Moreover, UK and US laws vary in the way repayment terms are modifiable (e.g. voting majority versus unanimity). The impact of such a settlement difference deserves further analysis as well, e.g. combining the analysis of the volumes of issues with returns. 


\section{References}

Atkeson, T.B. and S.D. Ramsey, Proposed Amendment of the Foreign Sovereignty Immunities Act, American Journal of International Law 79(3), 770-789.

Ayotte, K.M. and D.A. Skeel, 2002, Why do Distressed Companies Choose Delaware? Venue Choice and Court Experience in Bankruptcy, mimeo, Columbia Business School.

Bolton, P., 2002, Sovereign Debt Restructuring and Corporate Bankruptcy Law, mimeo, Princeton University, September.

Bolton, P. and O. Jeanne, 2002, Sovereign Debts Structuring and Restructuring: An Incomplete Contracts Approach, mimeo, Princeton University and International Monetary Fund, February.

Buchheit, L.C. and G.M. Gulati, 2002, Sovereign Bonds and the Collective Will, Georgetown University Law Center Woking Paper No. 34, March.

Bulow, J. and K. Rogoff, 1989, Sovereign Debt: Is to Forgive to Forget?, American Economic Review 79, 43-50, March.

Crawford, J., 1981, Execution of Judgements and Foreign Sovereign Immunity, American Journal of International Law 75(4), 820-869.

Delaume, G.R., 1994, The Foreign Sovereign Immunities Act and Public Debt Litigation: Some Fifteen Years Later, American Journal of International Law, Vol. 88, pp. 257-279.

Eichengreen, B. and A. Mody, 2000a, , Would Collective Action Clauses Raise Borrowing Costs?, NBER Working Paper no.7458, January.

Eichengreen, B. and A. Mody, 2000b, Would Collective Action Clauses Raise Borrowing Costs? An Update and Additional Results, Institute of Business and Economic Research Working Paper, Coo-114, May.

Eichengreen, B. and R. Portes, eds., 1995, Crisis? What Crisis? Orderly Workouts for Sovereign Debtors, Centre for Economic Policy Research, London.

Fabbri, D. and M. Padula, 2001, Judicial Costs and Household Debt, Center for Studies in Economics and Finance Working Paper No. 65, August.

Franks, J.R., W.N. Torous, 1994, Comparison of Financial Recontracting in distressed Exchanges and Chapter 11 Reorganizations, Journal of Financial Economics 35(3), 349370.

Franks, J.R., K.G. Nyborg, and W.N. Torous, 1996, Comparison of US, UK and German Insolvency Codes, Financial Management 25, 19-30.

Graaf, F., 1991, Euromarket Finance: Issues of Euromarket Securities and Syndicated Eurocurrency Loans, Kluwer, The Netherlands.

Greenwood, C. and H. Mercer, Considerations of International Law, in B. Eichengreen and R. Portes, ed., 1995, Crisis? What Crisis?, Annex 3, Centre for Economic Policy Research.

Heleniak, D.W., 1985, Sovereign Risks, in Pierce, D.G., H.H.M. Chan, F.E. Lacroix, and P.N. Pillai (eds.), Current Issues of International Financial Law, National University of Singapore, Singapore.

Jappelli, T., M. Pagano and M. Bianco, 2002, Courts and banks: Effects of Judicial Enforcement on Credit Markets, Center for Economic Policy Research Discussion Paper No. 3347, April. 
Kletzer, K.M., 2002, Sovereign Bond Restructuring: Collective Action Clauses and Official Crisis Intervention, University of California at Santa Cruz, Mimeo, December.

Krueger, A., 2002, A new Approach to Sovereign Debt Restructuring, International Monetary Fund, Washington, D.C., April.

Available at http://www.imf.org/external/pubs/ft/exrp/sdrm/eng/sdrm.pdf

La Porta, R., F. Lopez-de-Silanes, A. Shleifer, and R.W. Vishny, 1997, Legal Determinants of External Finance, Journal of Finance 52, 1131-1150.

La Porta, R., F. Lopez-de-Silanes, A. Shleifer, and R.W. Vishny, 1998, Law and Finance, Journal of Political Economy 106(6), 1113-1155.

La Porta, R., F. Lopez-de-Silanes, A. Shleifer, 1999, Corporate Ownership around the World, Journal of Finance 54, 471-517.

Leigh, M., 1984, Allied Bank International v. Banco Credito Agricola de cartago. 566 F.Supp. 1440, American Journal of International Law 78(2), 441-443.

Manove, M., J. Padilla, and M. Pagano, 2001, Collateral vs. Project Screening: A Model of Lazy Banks, RAND Journal of Economics 32(4), Winter, 726-744.

Mayer, C. and O. Sussman, 2001, The Assessment: Finance, Law, and Growth, Oxford Review of Economic Policy 17(4), 457-466.

Morris, S. and H.S. Shin, 2002, Coordination Risk and the Price of Debt, Cowles Foundation Discussion Paper No. 1241R, February.

Pizzurro, J.D., 1992, Republic of Argentina v. Weltover, Inc., American Journal of International Law 86(4), 820-824.

Rhodes, T., 3rd ed., 2001, Syndicated Lending, Practice and Documentation, Euromoney, London.

Rose, A., 2002, One Reason Countries pay their Debts: Renegotiation and International Trade, Centre for Economic Policy Research Discussion Paper No. 3157, January.

Schleifer, A., 2003, Will Sovereign Debt Market Survive?, American Economic Review, Forthcoming.

Schwarcz, S.L., 2000, Sovereign Debt Restructuring: A Bankruptcy Reorganization Approach, Cornell Law review, May.

Smit, H., N.M. Galston, S.L. Levitsky, eds., 1981, International Contracts, Parker School of Foreign and Comparative Law, Columbia University, Matthew Bender, New York.

Smith, C.W. and J.B. Warner, 1979, On Financial Contracting: An Analysis of Bond Covenants, Journal of Financial Economics 7, 1117-1161.

Tennekoon, R.C., 1991, The Law \& Regulation of International Finance, Butterworths, London.

White, M., 2002, Sovereigns in Distress: Do they need Bankruptcy?, Brookings Papers on Economic Activity 1, 287-319.

Wood, P.R., 1995, Law and Practice of International Finance, Sweet\&Maxwell, London.

Yianni, A., 1999, Resolution of Sovereign Financial Crises - Evolution of the Private Sector Restructuring Process, London School of Economics Financial Stability Review, June, 78-84. 


\section{Table I}

\section{Adoption of the Restrictive Doctrine of Foreign State Immunity}

Although sovereign immunity remains the general rule, a certain degree of restriction on immunity has been implemented in various jurisdictions. This table suggests a review of the deimmunisation and the adoption of the restrictive view of sovereign immunity. Distinction of legal origin follows La Porta et al. (1998). Rule of law is the assessment by investors of law enforcement (average over the period 1982-1995); scale from zero to 10; source: La Porta et al. (1997). Main source: Delaume (1994) and Wood (1995).

\begin{tabular}{|c|c|c|}
\hline Country & Rule of Law & Act / Case law \\
\hline \multicolumn{3}{|l|}{ English origin } \\
\hline Australia & 10.00 & Foreign Sovereign Immunity Act, 1985 \\
\hline Canada & 10.00 & Canadian State Immunity Act, 1982 \\
\hline Pakistan & 3.03 & Pakistan State Immunities Ordinance, 1981 \\
\hline Singapore & 8.57 & Singapore State Immunity Act, 1979 \\
\hline South Africa & 4.42 & South-Africa Foreign State Immunity Act, 1981 \\
\hline United Kingdom & 8.57 & State Immunity Act, 1978 \\
\hline United States & 10.00 & Foreign State Immunity Act, 1976 \\
\hline \multicolumn{3}{|l|}{ French origin } \\
\hline Belgium & 10.00 & $\begin{array}{l}\text { Since 1879: building contracts and trade. } \\
\text { Mahieu, Brasseur v. République Hellénique, Judgement of May 24, 1933, Cass. }\end{array}$ \\
\hline France & 8.98 & $\begin{array}{l}\text { Despite recent changes, historically narrow view of the restrictive doctrine. Execution is by no means clear. } \\
\text { Société Transhipping v Federation of Pakistan, } 47 \text { ILR (1966) } 150 \\
\text { Administration des Chemins de Fer du Gouvernement Iranien v Société Levant Express Transport, } 52 \text { ILR (1969) } \\
315 \text { (immunity held: acte de puissance publique) } \\
\text { Spanish State v SA L'Hôtel George V, } 65 \text { ILR (1984) } 61 \\
45 \text { ILR 74, Turkey deimmunised on a bank loan guarantee }\end{array}$ \\
\hline Greece & 6.18 & Athenian Court of Appeal, Annual Digest 6 (1949) 291 \\
\hline Italy & 8.33 & $\begin{array}{l}\text { US v Irsa, } 65 \text { ILR (1963) } 262 \\
\text { Consorzio Agrario di Tripolitania Case, } 65 \text { ILR (1966) } 265\end{array}$ \\
\hline Netherlands & 10.00 & $\begin{array}{l}\text { Société Européenne d'Études v Yugoslavia, } 65 \text { ILR (1973) } 356 \\
\text { Parsons v Malta, } 65 \text { ILR (1977) } 371\end{array}$ \\
\hline
\end{tabular}


Table I (continued)

\section{Adoption of the Restrictive Doctrine of Foreign State Immunity}

Although sovereign immunity remains the general rule, a certain degree of restriction on immunity has been implemented in various jurisdictions. This table suggests a review of the deimmunisation and the adoption of the restrictive view of sovereign immunity. Distinction of legal origin follows La Porta et al. (1998). Rule of law is the assessment by investors of law enforcement (average over the period 1982-1995); scale from zero to 10; source: La Porta et al. (1997). Main source: Delaume (1994) and Wood (1995).

\begin{tabular}{|c|c|c|}
\hline Country & Rule of Law & Act / Case law \\
\hline \multicolumn{3}{|c|}{ German origin } \\
\hline Austria & 10.00 & Dralle v Republic of Czechoslovakia 17 ILR (1950) 155 \\
\hline \multirow[t]{6}{*}{ Germany } & 9.23 & Article 25, Basic Law of the Federal Republic of Germany \\
\hline & & $\begin{array}{l}\text { "The general rules of international law shall form part of federal law. They shall take precedence over the laws and } \\
\text { create rights duties directly for the inhabitants of the federal territory." }\end{array}$ \\
\hline & & Claim v Empire of Iran, 45 ILR (1963) 57 \\
\hline & & Munich court, 1977 ELD 23 \\
\hline & & Central Bank of Nigeria Case, 65 ILR (1975) 131 \\
\hline & & NIOC Pipelines Contracts Case, 65 ILR (1982) 212 \\
\hline \multirow[t]{2}{*}{ Switzerland } & 10.00 & $\begin{array}{l}\text { Very restrictive view of immunity related to loan transactions since the Dreyfus case, } 1918 \text {. The Swiss courts require } \\
\text { however substantial connection (Binnenbeziehung) between the claim and the exercise of the Swiss jurisdiction (for } \\
\text { example, where payment is required by the contract to be made in Switzerland). Jurisdiction is otherwise declined. }\end{array}$ \\
\hline & & $\begin{array}{l}\text { Austrian Minister of Finance v. Dreyfus, } 44 \text { ATF I } 49 \text { (1918). } \\
\text { République Hellénique v. Walder, Judgement of Mar. 18, 1930, Trib. fed., ATF } 65 \text { I } 237 \\
\text { Royaume de Grèce v. Bank Julius Bär \& et Cie., Judgement of Mar. 18, 1930, Trib. fed., ATF } 65 \text { I } 237\end{array}$ \\
\hline \multicolumn{3}{|c|}{ Scandinavian origin } \\
\hline Denmark & 10.00 & Czechoslovakia v Jens Bygge Enterprises A/S, Supreme Ct, 1982, IIIJPI(1984) 639. Embassy construction. \\
\hline
\end{tabular}




\section{Table II}

\section{Currency Denomination, Listing Markets, and the Governing Law of Sovereign Eurobonds}

The table lists national laws that govern one or more emerging markets sovereign eurobonds in the period, January 1987 to December 1997 , and their associated currency and listing markets. First column reports the governing law. Second column reports the rule of law, namely the assessment by investors of law enforcement (average over the period 1982-1995); scale from zero to 10; source: La Porta et al. (1997). The third column reports the number of contracts governed by the respective laws. The fourth column reports the number of loans that are listed in the same country as the governing law. Column five reports the number of private placements. Column six reports the number of loans designed with the same country of currency as the governing law. Seventh column reports the number of contracts that either are listed in the same country or have the same currency as the governing law. Eighth column reports the number of contracts that report no listing markets. Last column reports the total amounts of debts governed by each law in millions of constant 1995 US dollars. Note that the securities may be traded in several markets. In addition, private placements are never listed so that listing and private placements are two exclusive features.

\begin{tabular}{|c|c|c|c|c|c|c|c|c|}
\hline Governing Law & $\begin{array}{c}\text { Rule } \\
\text { of Law }\end{array}$ & $\begin{array}{l}\text { Number of } \\
\text { contracts }\end{array}$ & $\begin{array}{l}\text { One listed market } \\
=\text { governing law }\end{array}$ & $\begin{array}{c}\text { Private } \\
\text { placements }\end{array}$ & $\begin{array}{c}\text { Currency } \\
=\text { Governing law }\end{array}$ & $\begin{array}{c}\text { One listing market or } \\
\text { currency = Governing law }\end{array}$ & $\begin{array}{l}\text { Unknown } \\
\text { Listing }\end{array}$ & $\begin{array}{l}\text { Volumes in } \\
\text { million } 1995 \text { USD }\end{array}$ \\
\hline Austria & 10.00 & 2 & 2 & 0 & 2 & 2 & 0 & 165 \\
\hline England & 8.57 & 117 & 11 & 19 & 6 & 14 & $\mathbf{0}$ & 30,646 \\
\hline Germany & 9.23 & 66 & 65 & 0 & 66 & 66 & 1 & 22,187 \\
\hline Japan & 8.98 & 49 & 29 & 19 & 49 & 49 & 1 & 13,089 \\
\hline Luxembourg & n.a. & 1 & 1 & 0 & 0 & 1 & 0 & 472 \\
\hline New York & 10.00 & 85 & 8 & 15 & 72 & 72 & 3 & 47,877 \\
\hline Spain & 7.80 & 2 & 2 & 0 & 2 & 2 & 0 & 159 \\
\hline Switzerland & 10.00 & 5 & 4 & 1 & 5 & 5 & 0 & 513 \\
\hline Unknown & - & 2 & . & 1 & . & . & 1 & 314 \\
\hline Total & & 329 & 130 & 55 & 202 & 211 & 6 & 115,517 \\
\hline
\end{tabular}


Table III

The Selection between England and New York Law by Issuing Country

The table lists sovereign states that issued Eurobonds in the period, January 1987 to December 1997. The sample is constituted of 327 observations. For each country, I report the number and total amounts (in millions of 1995 USD) of eurobonds issued under the English and New York laws as well as their shares.

\begin{tabular}{|c|c|c|c|c|c|c|c|c|c|c|}
\hline Country & Observations & England & $\%$ & New York & $\%$ & Amounts & England & $\%$ & New York & $\%$ \\
\hline Argentina & 81 & 47 & 58.0 & 10 & 12.3 & 30,679 & 12,841 & 41.9 & 9,208 & 30.0 \\
\hline Barbados & 4 & 3 & 75.0 & 0 & 0.0 & 130 & 100 & 76.4 & 0 & 0.0 \\
\hline Bulgaria & 2 & 2 & 100.0 & 0 & 0.0 & 104 & 104 & 100.0 & 0 & 0.0 \\
\hline China & 15 & 2 & 13.3 & 7 & 46.7 & 4,874 & 557 & 11.4 & 2,909 & 59.7 \\
\hline Colombia & 16 & 1 & 6.3 & 11 & 68.8 & 3,497 & 188 & 5.4 & 2,693 & 77.0 \\
\hline Ecuador & 2 & 0 & 0.0 & 2 & 100.0 & 520 & 0 & 0.0 & 520 & 100.0 \\
\hline Guatemala & 1 & 0 & 0.0 & 1 & 100.0 & 156 & 0 & 0.0 & 156 & 100.0 \\
\hline Indonesia & 1 & 0 & 0.0 & 1 & 100.0 & 408 & 0 & 0.0 & 408 & 100.0 \\
\hline Jamaica & 1 & 0 & 0.0 & 1 & 100.0 & 208 & 0 & 0.0 & 208 & 100.0 \\
\hline Kazakhstan & 2 & 1 & 50.0 & 1 & 50.0 & 573 & 206 & 40.0 & 368 & 64.2 \\
\hline Lebanon & 5 & 3 & 60.0 & 1 & 20.0 & 1,361 & 787 & 57.8 & 420 & 30.9 \\
\hline Lithuania & 3 & 3 & 100.0 & 0 & 0.0 & 320 & 320 & 100.0 & 0 & 0.0 \\
\hline Malaysia & 8 & 2 & 25.0 & 0 & 0.0 & 908 & 331 & 36.5 & 0 & 0.0 \\
\hline Mexico & 38 & 5 & 13.2 & 19 & 50.0 & 28,493 & 1,472 & 5.2 & 19,237 & 67.5 \\
\hline Moldova & 2 & 2 & 100.0 & 0 & 0.0 & 109 & 109 & 100.0 & 0 & 0.0 \\
\hline Oman & 1 & 1 & 100.0 & 0 & 0.0 & 234 & 234 & 100.0 & 0 & 0.0 \\
\hline Pakistan & 3 & 3 & 100.0 & 0 & 0.0 & 612 & 612 & 100.0 & 0 & 0.0 \\
\hline Panama & 2 & 1 & 50.0 & 1 & 50.0 & 1,255 & 735 & 58.6 & 520 & 41.4 \\
\hline Philippines & 4 & 2 & 50.0 & 0 & 0.0 & 1,227 & 850 & 69.3 & 0 & 0.0 \\
\hline Poland & 4 & 1 & 25.0 & 2 & 50.0 & 831 & 247 & 29.8 & 416 & 50.1 \\
\hline Romania & 1 & 0 & 0.0 & 0 & 0.0 & 362 & 0 & 0.0 & 0 & 0.0 \\
\hline Russia & 4 & 3 & 75.0 & 0 & 0.0 & 4,748 & 3,530 & 74.4 & 0 & 0.0 \\
\hline Slovenia & 2 & 1 & 50.0 & 0 & 0.0 & 578 & 331 & 57.3 & 0 & 0.0 \\
\hline South Africa & 10 & 3 & 30.0 & 3 & 30.0 & 4,021 & 481 & 11.9 & 2,285 & 56.8 \\
\hline Sri Lanka & 1 & 1 & 100.0 & 0 & 0.0 & 52 & 52 & 100.0 & 0 & 0.0 \\
\hline Thailand & 15 & 0 & 0.0 & 2 & 13.3 & 2,460 & 0 & 0.0 & 894 & 36.3 \\
\hline Trinidad \& Tobago & 7 & 2 & 28.6 & 2 & 28.6 & 650 & 212 & 32.6 & 300 & 46.2 \\
\hline Tunisia & 2 & 0 & 0.0 & 2 & 100.0 & 153 & 0 & 0.0 & 153 & 100.0 \\
\hline Turkey & 59 & 21 & 35.6 & 7 & 11.9 & 16,738 & 5,495 & 32.8 & 1,342 & 8.0 \\
\hline Ukraine & 1 & 0 & 0.0 & 0 & 0.0 & 473 & 0 & 0.0 & 0 & 0.0 \\
\hline Uruguay & 8 & 0 & 0.0 & 5 & 62.5 & 1,019 & 0 & 0.0 & 696 & 68.3 \\
\hline Venezuela & 22 & 7 & 31.8 & 7 & 31.8 & 7,355 & 851 & 11.6 & 5,144 & 69.9 \\
\hline Total & 327 & 117 & 35.8 & 85 & 26.0 & 115,108 & 30,645 & 26.6 & 47,877 & 41.6 \\
\hline
\end{tabular}




\section{Table IV}

\section{Combined Analysis of the Currency of Denomination and the Listing Markets by Governing Law}

The table lists national laws that govern non-private placement bonds issued between January 1987 and December 1997. Sovereign bonds are grouped by their currency of denomination (whether it is of the currency of the governing law state or not) and the listing markets (whether one of the listing markets at least is in the governing law jurisdiction). Private placements are excluded. The last column reports the number of bonds that are not listed in the governing law jurisdiction but are in Luxembourg. 322 bonds are reported in total. The difference with Table $\mathrm{V}$ is due to the absence of private placements and that five listing markets are not reported.

\begin{tabular}{|c|c|c|c|c|}
\hline Governing Law & Currency & $\begin{array}{l}\text { Listed in the state of the } \\
\text { governing law }\end{array}$ & $\begin{array}{l}\text { Listed in another } \\
\text { state }\end{array}$ & $\begin{array}{l}\text { Of which listed in } \\
\text { Luxembourg }\end{array}$ \\
\hline Austria & $\begin{array}{l}\text { Austrian Shilling } \\
\text { Other currency }\end{array}$ & $\begin{array}{l}1 \\
0\end{array}$ & $\begin{array}{l}1 \\
0\end{array}$ & $\begin{array}{l}1 \\
0\end{array}$ \\
\hline England & $\begin{array}{l}\text { English Pound } \\
\text { Other currency }\end{array}$ & $\begin{array}{l}3 \\
8\end{array}$ & $\begin{array}{r}3 \\
84\end{array}$ & $\begin{array}{r}3 \\
80\end{array}$ \\
\hline Germany & $\begin{array}{l}\text { German Mark } \\
\text { Other currency }\end{array}$ & $\begin{array}{r}65 \\
0\end{array}$ & $\begin{array}{l}0 \\
0\end{array}$ & $\begin{array}{l}0 \\
0\end{array}$ \\
\hline Japan & $\begin{array}{l}\text { Japanese Yen } \\
\text { Other currency }\end{array}$ & $\begin{array}{r}29 \\
0\end{array}$ & $\begin{array}{l}0 \\
0\end{array}$ & $\begin{array}{l}0 \\
0\end{array}$ \\
\hline Luxembourg & $\begin{array}{l}\text { Luxemburg Franc } \\
\text { Other currency }\end{array}$ & $\begin{array}{l}0 \\
1\end{array}$ & $\begin{array}{l}0 \\
0\end{array}$ & $\begin{array}{l}0 \\
1\end{array}$ \\
\hline New York & $\begin{array}{l}\text { US Dollar } \\
\text { Other currency }\end{array}$ & $\begin{array}{l}7 \\
0\end{array}$ & $\begin{array}{r}52 \\
8\end{array}$ & $\begin{array}{r}50 \\
6\end{array}$ \\
\hline Spain & $\begin{array}{l}\text { Spanish Peseta } \\
\text { Other currency }\end{array}$ & $\begin{array}{l}2 \\
0\end{array}$ & $\begin{array}{l}0 \\
0\end{array}$ & $\begin{array}{l}0 \\
0\end{array}$ \\
\hline Switzerland & $\begin{array}{l}\text { Swiss Franc } \\
\text { Other currency }\end{array}$ & $\begin{array}{l}4 \\
0\end{array}$ & $\begin{array}{l}0 \\
0\end{array}$ & $\begin{array}{l}0 \\
0\end{array}$ \\
\hline
\end{tabular}




\section{Table V}

\section{The Selection of the Governing Law in function of the Issuer Characteristics.}

The table reports the selection of the governing law of sovereign eurobonds in the period, January 1987 to December 1997. Lines include the individual loan amount normalized to issuer's GNP, the country total debt to GNP, and the yearly amounts raised from capital markets relative to GNP. Only main governing laws are reported in columns, namely England, Germany, New York, and Japan.

\begin{tabular}{lccccc}
\hline & England & Germany & Japan & New York & All sample \\
\hline $\begin{array}{l}\text { Individual bond amount to } \\
\text { GNP }(\%)\end{array}$ & 0.57 & 0.24 & 0.24 & 0.85 & 0.52 \\
Total debt to GNP $(\%)$ & 39.0 & 40.9 & 38.0 & 43.8 & 40.1 \\
Yearly amount to GNP $(\%)$ & 1.20 & 0.43 & 0.49 & 1.48 & 0.91 \\
\hline
\end{tabular}

\section{Table VI}

\section{Regression estimates}

The table reports the impact of the governing law on the funds available yearly relative to GNP in the period, January 1987 to December 1997. The dependent variable is the sum of primary issues of bonds for a given country relative to GNP (in percentage). The country dummies, Germany, Japan, and New York, are dummy variables that take 1 if the group of bonds is governed respectively by Germany, Japan and New York laws, 0 otherwise. England law is the omitted dummy variable and therefore is the benchmark. Debt to GNP is the indicator of creditworthiness of the issuing country.

\begin{tabular}{lccccc}
\hline & Germany & Japan & New York & Debt to GNP & Constant \\
\hline Yearly amount to GNP (\%) & -0.86 & -0.71 & 0.02 & 2.16 & 0.41 \\
& 0.00 & 0.03 & 0.92 & 0.00 & 0.16 \\
$\mathrm{R}^{2}=0.144 \quad$ Number of obs. $=181 \quad$ Prob $>\mathrm{F}=0.0 \quad \mathrm{~F}(4,176)=7.38$ & & \\
\hline
\end{tabular}




\section{CFS Working Paper Series:}

\begin{tabular}{ll} 
No. & Author(s) \\
\hline $2003 / 24$ & Tereza Tykvová
\end{tabular}

Title

Is the Behavior of German Venture Capitalists

Different? Evidence from the Neuer Markt

2003/25 Tereza Tykvová

2003/26 Stefanie Franzke

Stefanie Grohs

Christian Laux

2003/27 Andreas Hackethal

2003/28 Frank A. Schmid

Mark Wahrenburg

2003/29 Christina E. Bannier

2003/30 Markus Mentz

Steffen P. Sebastian

2003/31 Francis X. Diebold

Glenn D. Rudebusch

S. Boragan Aruoba

2003/32 Stefan Jaschke

Gerhard Stahl

Richard Stehle

2003/33 Issam Hallak

2003/34 Issam Hallak
The Role of the Value Added by the Venture

Capitalists in Timing and Extent of IPOs

Initial Public Offerings and Venture Capital in Germany

German banks - a declining industry?

Mergers and Acquisitions in Germany-Social

Setting and Regulatory Framework

Privacy or Publicity - Who Drives the Wheel?

Inflation convergence after the introduction of the Euro

The Macroeconomy and the Yield Curve:

A Nonstructural Analysis

Evaluating VaR Forecasts under Stress -

The German Experience

Bank Loans Non-Linear Structure of Pricing:

Empirical Evidence from Sovereign Debts

Courts and Sovereign Eurobonds: Credibility of the Judicial Enforcement of Repayment

Copies of working papers are available at the Center for Financial Studies or can be downloaded (http://www.ifk-cfs.de). 